\title{
EARLY DIAGNOSIS AND EARLY THERAPY IN CONGENITAL CRETINISM
}

\author{
BY \\ Y. ÅKERRÉN \\ From the Medical Department, Children's Hospital, Gothenburg, Sweden
}

(RECEIVED FOR PUBLICATHON NOVEMBER 25, 1954)

How soon can the diagnosis of congenital cretinism be made? Isolated cases have been diagnosed at birth (Abels, 1911). There is a photograph in Potter's (1952) monograph showing an infant at the age of 1 month with the typical facies; the case had been diagnosed and, judging by a later view, successfully treated by McIntosh (1952). Wieland (1940), who has great experience, claims that he observed some six or eight cases aged between 3 and 5 months, where the diagnosis was obvious at first sight. All these patients had previously been under the observation of other physicians for symptoms which definitely or very probably were connected with congenital cretinism. Wieland's most successful case, from the therapeutic point of view, was diagnosed and treated from the age of 5 months.

According to Higgins and Ingalls (1948) 'the first signs of cretinism will appear at the age of about 2 months, although the condition is seldom diagnosed before the child is 5 months old. Many larger series, especially of an early date, contain only few with an early diagnosis and therapy, e.g. Marvel's (1939) from Oslo. A fairly large series from Sweden (d'Avignon and Melin, 1949) with 22 cases includes 10 with a diagnosis made before the age of 5 months.

Why is the diagnosis so often made so late? Frequently the parents do not consult the physician early enough. Another and usual reason is that the physician does not recognize the picture of the disease at its early stage of development. This certainly also applies to paediatricians with great experience. Cases of congenital cretinism are so rare that only one or two per annum are diagnosed at the larger children's hospitals in Scandinavia. Finally, there are cases of mild congenital cretinism where the typical symptoms do not develop until later on, at the end of the first year of life or later.

In a previous paper (Åkerrén, 1954) I have been able to point out the frequent coincidence between congenital cretinism and icterus neonatorum prolongatus with a remarkable duration. In this investigation I combined 10 cases of congenital cretinism which also had shown signs of icterus with a duration of at least six weeks, but otherwise, as far as could be judged, of a physiological type. At an investigation carried out at the Children's Hospital of Gothenburg, including 946 newborn infants who were closely studied for the occurrence and duration of physiological icterus, Beskow, among others, found that the mean duration of icterus which lasted at least 48 hours was $11 \cdot 37 \pm 6 \cdot 20$. A duration of physiological icterus exceeding about 30 days must thus be very rare.

As shown in Table 1, early diagnosed cases of

TABLE 1

CASES WITH CONGENITAL MYXOEDEMA ADMITTED TO THE CHILDREN'S HOSPITAL, GOTHENBURG, BEFORE THE AGE OF 1 YEAR DURING 1922-54

\begin{tabular}{|c|c|c|c|}
\hline & \multicolumn{3}{|c|}{ Cases Admitted } \\
\hline & 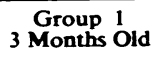 & $\begin{array}{l}\text { Group } 2 \\
\text { Between } 3 \text { and } \\
6 \text { Months Old }\end{array}$ & $\begin{array}{l}\text { Group } 3 \\
\text { Between } 6 \text { and } \\
12 \text { Months Old }\end{array}$ \\
\hline $\begin{array}{l}\text { Cases with pro- } \\
\text { longed icterus }\end{array}$ & 6 & $1 *$ & - \\
\hline $\begin{array}{l}\text { Cases without any } \\
\text { statement of icterus }\end{array}$ & 3 & 4 & 4 \\
\hline Total & 9 & 5 & 4 \\
\hline
\end{tabular}

- Had icterus to the age of 21 months.

congenital cretinism are unusual. In the table all the cases are given which were admitted to the Children's Hospital of Gothenburg before the age of 1 year, from 1922 up to and inclusive of the spring of 1954. They are in all 18. Of the nine babies admitted before they had reached the age of 3 months, no fewer than six had shown icterus with a duration of at least six weeks. Of the five babies 
admitted between the ages of 3 and 5 months, one had suffered from icterus up to the age of $2 \frac{1}{2}$ months.

The coincidence of comparatively unusual conditions, such as early diagnosed congenital cretinism and icterus of a remarkably long duration is not likely to be due to chance.

This coincidence has been mentioned in a few case reports but otherwise not observed or commented upon. The reason seems to be that even experienced paediatricians only rarely get an opportunity of seeing and diagnosing early cases of congenital cretinism. An infant who during the first months of life shows icterus neonatorum of remarkable duration should thus be carefully observed and examined until the diagnosis can be made or excluded with certainty.

Practically all textbooks and handbooks of paediatrics unanimously point out that an early diagnosis and adequate treatment are of greatest importance in the prognosis of mental development in congenital cretinism. The prognosis for the somatic symptoms is, generally, favourable even if the diagnosis is made comparatively late and the institution of treatment is delayed.

When studying publications which give a detailed report of the mental results of the treatment, with consideration to the time of its onset, the picture proves to be less clear and unquestionable. The last series of investigations on prognosis which I have been able to find was published by Topper (1951). The time for the onset of the treatment has there been combined with the I.Q., which was ascertained during a follow-up study. Regarding the mental development, Topper concludes that there is considerable evidence to show a lack of correlation between results obtained in the child with congenital hypothyroidism and adequacy of therapy; 7 , or $39 \%$, of the adequately treated patients have remained feebleminded in spite of this. These results are not correlated to the onset of therapy'.

d'Avignon and Melin (1949), from a series of 22 cases, come to almost the same conclusion as Topper, viz., that the time for the onset of the treatment is of no greater importance to the prognosis for the psychical development. 'Even when therapy was begun very early, the results were sometimes bad. Correspondingly, there were several cases of classic congenital hypothyrosis in which treatment was begun relatively late and yet the final results were good.'

Radwin, Michelson, Berman and Kramer (1949) found, in spite of considerable difference of the age at which thyroid was first started, that seven patients out of 10 display normal intelligence levels.
In some of them therapy had been started as early as 4 weeks, in others as late as 3 years.

The series by Topper, d'Avignon and Melin, and Radwin et al. are singly not large enough to be statistically studied. Neither have the authors expressed more exactly what they meant by early therapy. In Table 2 I have combined these three

TABLE 2

RELATION BETWEEN THE TIME OF STARTING TREATMENT WITH THYROID AND MENTAL DEVELOPMENT

\begin{tabular}{|c|c|c|c|}
\hline & & Treatment Begun & \\
\hline $\begin{array}{l}\text { No. of } \\
\text { Cases } \\
\text { with I.Q. }\end{array}$ & $\begin{array}{l}\text { Group 1: } \\
\text { Before Age of } \\
5 \text { Months }\end{array}$ & $\begin{array}{l}\text { Group 2: } \\
\text { From } 5 \text { Months } \\
\text { but before } \\
12 \text { Months }\end{array}$ & $\begin{array}{c}\text { Group 3: } \\
\text { From } 1 \text { Year } \\
\text { up to and } \\
\text { Including } 3 \text { Years }\end{array}$ \\
\hline $\begin{array}{r}\text { Below } 70 \\
70-79 \\
80-89 \\
90-110 \\
110\end{array}$ & $\begin{array}{l}2 \\
\overline{5} \\
8\end{array}$ & $\begin{array}{l}6 \\
2 \\
1 \\
4 \\
1\end{array}$ & $\begin{array}{r}4 \\
1 \\
2 \\
11 \\
2\end{array}$ \\
\hline $\begin{array}{l}\text { Total with } \\
\text { I.Q. below } \\
80 . .\end{array}$ & $\begin{array}{c}15 \\
2(13 \cdot 3 \%)\end{array}$ & $\begin{array}{c}14 \\
8(57 \cdot 1 \%)\end{array}$ & $\begin{array}{c}20 \\
5(25 \cdot 0 \%)\end{array}$ \\
\hline
\end{tabular}

series. I have then excluded the cases where the treatment has been indicated as inadequate, or where the treatment was started later than at the newly reached age of 3 years. One case has been excluded from Topper's series, where the final results regarding the mental development was 'defective', there being a psychosis present, but where the I.Q. was high.

The differences between the frequency of an I.Q. of less than 80 in the various groups has been statistically analysed by means of the $X^{2}$ method. Between groups 1 and 2 there is a difference significant at the $5 \%$ level. Between groups 1 and 3 and 2 and 3 there is no statistically significant difference.

Judging by the statistical study of the series combined here, it seems justifiable to conclude that treatment started before the age of 5 months gives more hope of a favourable result than treatment begun later on. It may seem remarkable that such a comparatively large number of the results obtained in group 3 are favourable, although these results do not differ in a statistically significant way from those obtained in group 2. This is probably due to the fact that this group is likely to be less homogeneous than the other two. Thus it includes some severe cases where the therapy was begun late with a bad result as a sequel, but it probably also includes some slight cases in which it was impossible to make the diagnosis earlier. In these cases the insufficiency of thyroid has not been severe. The central nervous system and especially the brain have not been 
subjected to such early damage from or early after birth as when there is an already severely deficient thyroid function. The results have, therefore, to rather a large extent been successful.

Table 3 illustrates, although it is not sufficiently

TABLE 3

DISTRIBUTION OF CASES WITH I.Q. BELOW 70 TO ONSET OF TREATMENT

\begin{tabular}{lll}
\hline Group 1 & No. of Cases \\
\cline { 2 - 4 } & Group 2 & Group 3 \\
\hline
\end{tabular}

\begin{tabular}{llll}
$\begin{array}{l}\text { I.Q. less } \\
\text { than } \begin{array}{c}30 \\
30-50 \\
51-69\end{array}\end{array}$ & - & 3 & - \\
\hline Total & 2 & 1 & 1 \\
\hline
\end{tabular}

extensive for statistical studies, the differences in results between the three groups. The table shows that the most severe disturbances with I.Q. below 30 only occur in group 2 and that in no case where the treatment was begun before the age of 5 months was an I.Q. below 51 found.

\section{Summary}

There is an obvious coincidence between congenital cretinism and icterus neonatorum of excessive duration. In babies with congenital cretinism who come under observation before the age of 3 months, icterus seems to be very frequent.

The knowledge of this syndrome must be assumed to be of practical importance for the early diagnosis of congenital cretinism. In cases of icterus neonatorum of excessive duration careful observation and examination must be performed until the diagnosis can either be made or excluded.

In cases of severe congenital cretinism early treatment, i.e., beginning before the approximate age of 5 months, gives a much greater chance of obtaining a favourable mental prognosis than if the treatment is started later.

As an early diagnosis of congenital cretinism is a reason for early adequate therapy, the knowledge of the congenital cretinism-icterus neonatorum syndrome is of value from the therapeutic and prognostic points of view.

\section{REFERENCES}

Abels, H. (1911), Wien, klin. Wschr., 24, 1581 , Quot. after Wieland. Åkerrén, Y. (1954). Acta paediat. Uppsala, 43, 411.

d.Avignon, M. and Melin, K.-A. (1949). Ibid., 38, 37.

Higgins, H. L. and Ingalls, T. H. (1948). The Child in Health and Disease, p. 840, by C. G. Grulee and R. C. Eley. Baltimore. McIntosh. R. (1952). Ouoted from Potter, p. 278 .

Marvel, O. (1939). Acta paediat., Uppsala, 24, 214. (Proc. 7th Northern Pediatric Congress, Oslo, 1938).

Potter, E. L. (1952). Pathology of the Fetus and the Newborn. Chicago.

Radwin, L. S., Michelson, J. P.. Berman, A. B. and Kramer, B. (i949). Amer. J. Dis. Child., 78, 821.

Topper, A. (1951). Ibid., 81, 233.

Wieland, E. (1940). Die Athyreosis und Hypothyreosis im Kindesalter. Wilkins, L. (1950). The Diagnosis and Treatment of Endocrine Disorders in Childhood and Adolescence. Springfield, Illinois. 